\title{
ENGLISH INTRODUCTION THROUGH DIGITAL STORYTELLING IN EARLY CHILDHOOD
}

\author{
Gaya Tridinanti \\ Tridinanti University Of Palembang, Indonesia \\ gayatridinanti@gmail.com
}

\begin{abstract}
The introduction of simple English sentences to early childhood is not an easy task. This is often a problem for teachers. The purpose of this study is to investigate the introduction of the English language by using a digital storytelling. This research is an action research. Subjects of research include 20 children from group B (5-6 years) of Happy Kids Kindergarten in Palembang. The finding shows that there is an enhancement in pre-cycle is 33\%, to 59\% in Cycle I. In Cycle II is $79 \%$ and in Cycle III is $97 \%$. Thus, an increase of $26 \%$ from the pre-cycle to cycle I. Increased $20 \%$ from Cycle I to Cycle II and increased 18\% from Cycle II to Cycle III. The result of the English introduction action through digital storytelling in early childhood shows a significant percentage increase from cycle I to cycle II, and cycle III. The increase in percentage indicates that the use of digital storytelling can improve the process and the results of early childhood English introduction in terms of meaning, show, imitate, and say simple English sentences Therefore, digital storytelling based learning can be incorporated in the curriculum of Kindergarten.
\end{abstract}

Keywords: English introduction, digital storytelling, early childhood.

In daily life, the language can not be separated from human life. Language is one of the aspects of child development that are essential for stimulated from an early age. Language is also a major contribution to the development of a child. An early age is crucial to the children's growth and development for the future. Therefore, in early childhood education, educators are required to understand the ability of the child, including the child's language ability. Mundhe (2015) states that language skills are divided into two, namely: receptive and expressive. The receptive skill is understanding, whereas expressive one is the expression or speech. There are four skills in English Language, one is the receptive and another is the productive skill. In receptive skills, it includes two skills: listening and reading skills and in productive skills, one is speaking and writing (p.1).

Early childhood's English introduction can not be equated with teenagers and adults. Early childhood's English introduction was limited in simple sentences that are often encountered in the environment. Kreshen (2002) states that language introduction is very similar to the process children use in acquiring first and second languages. It requires meaningful interaction in the target language--natural communication--in which speakers are concerned not with the form of their utterances but with the messages they are conveying and understanding (p. 1). According to research conducted by Rahmat (2010) shows that in Indonesia, in the last 10 years showed that early childhood education institutions or Kindergarten kept racing to develop a program of Foreign Language (English, Arabic, Mandarin) as one of the expertise developed and dominated by children. Even for the managers believe that the value and popularity of Kindergarten is largely determined by the quality of foreign language taught and mastered by children (pp: 78-79). 
Along with advances in information and communications technology, storytelling developed in digital form known as digital storytelling. Ware (2006) states, "Naturally children can use traditional storytelling to express themselves. However children awareness and confidence to tell an interesting story that will grasp the audience's attention is increased through digital storytelling." (pp. 45-54). This is grounded as stated by Bratitsis and Ziannas (2015) that digital storytelling is the combination of traditional, oral narration with multimedia and communication tools. It is a form of art which combines different types of multimedia material, including images, text, video clips, audio narration and music to tell a short story on a particular topic or theme. (p. 233). Likewise according to Robin (2016) that digital storytelling combines the art of telling stories with a mixture of digital media, including text, pictures, recorded audio narration, music and video. These multimedia elements are blended together using computer software, to tell a story that usually revolves around a specific theme or topic and often contains a particular point of view (p.18).

The appropriate use of ICT allows children to develop language skills Jonassen and Hernandez-Serrano (2002) state that there are three ways to support learning through storytelling. First, they can be used as examples of notions or values that have been taught with direct learning. Second, they can be presented as problems to be solved by the students. Third, stories can have an advisory role and help students solve problems (pp. 65-77). Storytelling and learning are inextricably intertwined because the process of composing a story is also a process of meaning making. Integrating opportunities for "storytelling" into coursework strengthens course participant learning. DeNatale (2008) stated that through storytelling, students are asked to reflect on what they know, to examine their (often unquestioned) assumptions, and - through a cyclical process of revision - to record their "cognitive development process." Because the stories provide a record of students' thinking, teachers can use them in assessing student progress toward learning goals (p. 2).

Various methods have been applied in introducing English vocabulary to early childhood, but the results have not been up. Based on observations of children aged 5-6 years old of B Group at Happy Kids Kindergarten in Palembang shows that teachers often have difficulties in introducing English vocabulary to early childhood. Results of pre-cycle that was conducted in September 2016 showed that of the 20 children expected to attend, only 15 children were present. Of that number, no one gets a score of 3 (three) or Grows Up Expectations let alone 4 (four) or Very Good Develops. They only get a score of 1 (one) or Not Developed and 2 (two) or Start Developing for each assessment indicator, that is: to interpret, to show, to imitate and to say..

Observing the problems of English introduction for young children above, then the solution is needed in order to provide optimal results in the process of learning English. One of them is by applying the method of digital storytelling. Robin (2016) states that one of the most important aspects of digital storytelling is that it can make learning more relevant for students. Digital storytelling can encourage creativity as well as give students a voice as they use their stories to share their ideas and feelings with others (p. 11). This study aims to know the introduction of English through digital storytelling in early childhood. While in particular, this study aims to know both the process and the results of the introduction of English through digital storytelling in early childhood.

\section{METHOD}

\section{Participants}

The subjects were children in B group totaling of 20 children (5-6 years old). 


\section{Assessments and Measures}

The method used is Action Research. This action research was conducted at Happy Kids Kindergarten in Palembang. Before carrying out this research, researcher formulated and established a research procedure that consists of four stages: planning, implementation, observation, and reflection. The implementation of this research was conducted collaboratively with classroom teachers. Data analysis performed in this study is a qualitative descriptive by using an interactive model, namely data reduction, data presentation, and conclusions. To determine the success and effectiveness of research is defined performance indicators.

\section{Cycle I}

\section{RESULTS AND DISCUSSION}

In Cycle I, the average percentage of group B children of Happy Kids Kindergarten in Palembang in saying simple English sentences is as follows: Not Grow 25\%; Start Developing 45\%; Expanding by Expectation 30\%; And Growing Very Good 0\%. Thus most of the children in the Beginning Class category mean that in recognizing simple English sentences, the children still have to be reminded or assisted by the teacher.

The result shows that the average percentage of the introduction of simple English sentences of group B children of Happy Kids Kindergarten in Palembang reached 59\%. Thus the average percentage of the introduction of simple English sentences for the introduction of simple English sentences of group B children of Happy Kids Kindergarten in Palembang is still in the category has not met the success criteria of action (85\%), although there is a $26 \%$ increase from Pre-cycle (33\%).

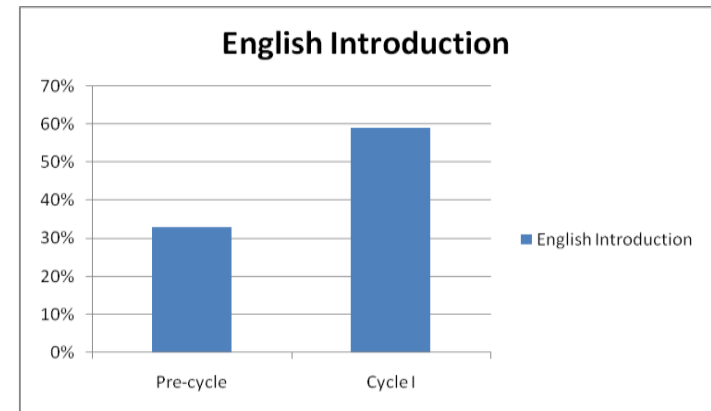

Figure 1. Enhancement of Children's English Introduction

Through Digital Storytelling from Pre-cycle to Cycle I

\section{Cycle II}

In Cycle II, the average percentage of group B children of Happy Kids Kindergarten in Palembang in saying simple English sentences is as follows: Not Developed 0\%; Start Developing 5\%; Expanding According to Hope 80\%; And Growing Very Good 15\%. Thus most children in the category of Growing Up Expectation means that in recognizing simple English sentences, the child must still be reminded or assisted by the teacher. The result shows that the average percentage of the introduction of simple English sentences of group B children of Happy Kids Kindergarten in Palembang reached $79 \%$. Thus the average percentage of the introduction of simple English sentences of the group B children of Happy Kids Kindergarten in Palembang is still in the category has not met the success criteria of the action (85\%), although there is a $20 \%$ increase from Cycle I $(59 \%)$ and $46 \%$ from Pre-cycle (33\%). 


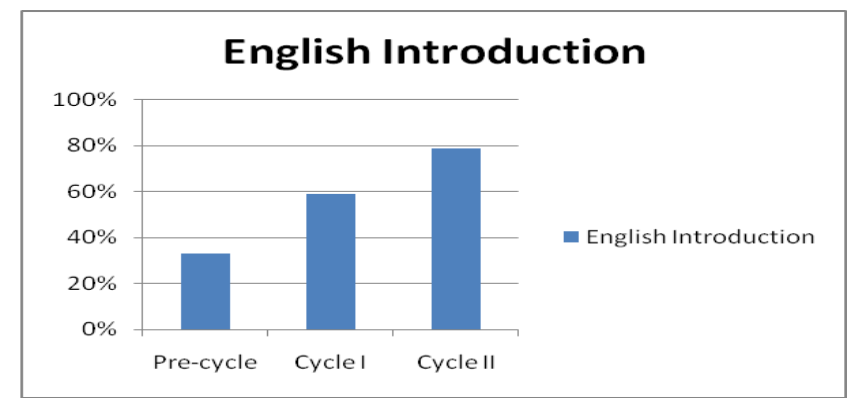

Figure 2. Enhancement of Children's English Introduction Through Digital Storytelling from Pre-cycle to Cycle I and to Cycle II

\section{Cycle III}

In Cycle III, the average percentage of group B children of Happy Kids Kindergarten in Palembang in saying simple English sentences is as follows: Not Developed 0\%; Start Developing 0\%; Expanding by Expectation 10\%; And Growing Very Good 90\%. Thus most children in the category of Very Good Growing means children are able to know simple English sentences independently and can help their friends who do not know a simple sentence. The result shows that the average percentage of the introduction of simple English sentences of group B children of Happy Kids Kindergarten in Palembang reached 97\%. Thus the average percentage of the introduction of simple English sentences of group B children of Happy Kids Kindergarten in Palembang in the category has met the success criteria of action $(85 \%)$, there is an $18 \%$ increase of the Cycle II (79\%), 38\% increase from Cycle I (59\%) and 64\% from Pre-cycle (33\%). The final results can be seen below:

Table 1 Children's English Introduction of B Group of Happy Kids Kindergarten in Palembang

\begin{tabular}{|l|c|c|c|c|}
\hline \multirow{2}{*}{\multicolumn{1}{|c|}{ Aspect }} & \multicolumn{4}{|c|}{ Percentage per Cycle } \\
\cline { 2 - 5 } & Pre-Cycle & Cycle I & Cycle II & Cycle III \\
\hline $\begin{array}{l}\text { The Children's } \\
\text { English introduction }\end{array}$ & $33 \%$ & $59 \%$ & $79 \%$ & $97 \%$ \\
\hline Success criteria & $\geq 75 \%$ & $\geq 75 \%$ & $\geq 75 \%$ & $\geq 75 \%$ \\
\hline Enhancement & - & $26 \%$ & $20 \%$ & $18 \%$ \\
\hline
\end{tabular}

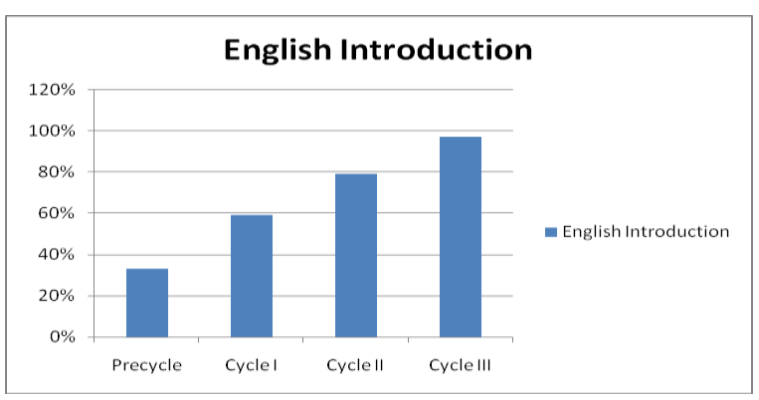

Figure 3. Enhancement of Children's English Introduction Through Digital Storytelling

In Cycle I, the average percentage of the introduction of simple English sentences of group B children of Happy Kids Kindergarten in Palembang (59\%) is still in the category has not met the 
success criteria of action (85\%), although there is an increase of $26 \%$ from Pre cycle (33\%). This $26 \%$ increase is in accordance with the attitude of children in digital storytelling activities using power point presentations media that have not been able to attract children's attention maximally. Teachers are not used to digital storytelling has an impact on the attitude of children. Digital storytelling activities are not easy, this is reasonable because it involves a combination of narration and use of multimedia. Bratitsis and Ziannas (2015) stated that digital storytelling is basically a combination of traditional oral narration with multimedia and communication tools. It is an art form that combines different types of multimedia materials, including images, text, video clips, audio and music narration to tell a short story on a particular topic or theme. (p.233) Therefore, teachers should be familiar with digital storytelling and impressions should also be interesting so that children can enjoy the story.

In Cycle II, the average percentage of simple English sentences for children of Group B in Happy Kids Palembang reached $79 \%$. Thus the average percentage of the introduction of simple English sentences of the group B children in Kindergarten Happy Kids Palembang is still in the category has not met the success criteria of the action (85\%), although there is a $20 \%$ increase from Cycle I (59\%) and 46\% Of Pre cycle acquisition (33\%). Teachers are getting used to digital storytelling, even the teacher also improves the show in the form of story jumper. This has led children to focus on the story and introduction of simple English sentences conveyed by the teacher. Digital storytelling, should interest children both the story and the delivery. Digital-based stories can capture children's attention. Lathem, as quoted by Papadimitriou et al. (2013) stated that digital storytelling is a combination of traditional oral stories with 21 st century multimedia and ICT tools. It is a process that combines digital media to enrich and enhance written or oral stories. (p.389) Similarly Mallan, as quoted by Phillip (2016) states that, telling is clearly a social experience with oral narrative, combining linguistic features that display "sophistication that goes beyond the level of conversation." (p.1) Thus, interesting digital storytelling can help the child in connection with the introduction of simple English sentences as one form of oral competence.

In Cycle III, the average percentage of simple English sentences for children of Group B in Happy Kids Palembang reached 97\%. Thus the average percentage of the introduction of simple English sentences of group B children in Happy Kids Palembang Kindergarten in the category has met the success criteria of action (85\%), there is an increase of $18 \%$ from the acquisition of Cycle II (79\%), there is an increase of 38\% Of Cycle I (59\%) and 64\% from Pre cycle (33\%). Teacher is familiar with the digital storytelling and can tell the story comfortably. Especially in the third cycle of teachers using animation film in the form of live images with sound effects in accordance with the situation to make the child can enjoy and interact with his teacher maximum. Razmi, Pourali, and Nozad (2014) stated that introducing digital storytelling as a high-quality technology to collect, create, examine, and merge visual images with text. (p. 1542). Integrating visual images with written texts can expand and accelerate students' understanding by increasing interest in finding new ideas. Similarly, according to Tendero (2006:) that digital storytelling is very helpful to teachers in the introduction of English. (p.172) Digital stories are efficient in facilitating the teacher's efforts to capture class moments to reflect and revise practices, as well as to develop teaching awareness. Thus, the application of interesting digital storytelling can help the introduction of simple English language sentences of early childhood.

\section{CONCLUSSION}

The conclusion that can be drawn from the conduct of research for 3 cycles, as follows:

1. Introduction process of English through digital storytelling in early childhood interesting especially animated movie impressions make children enjoy the story while actively interacting 
with the teacher. Children are motivated to know English through the process of meaning, showing, imitating, and uttering simple sentences.

2. Introduction of English through digital storytelling in early childhood shows an increase in percentage from cycle I to cycle II, and cycle III. The increase in the average percentage of introduction of simple English sentences of early childhood suggests that the use of digital storytelling in general can help the introduction of early childhood English.

Thus it can be concluded that the use of digital storytelling can improve the process and the results of early childhood English introduction in terms of meaning, show, imitate, and say simple English sentences. The use of digital storytelling can help the introduction of English in early childhood. Therefore, digital storytelling based learning can be incorporated in the curriculum of Kindergarten.

\section{REFERENCES}

Bratitsis, Tharrenos and Petros Ziannas. (2015). From Early Childhood to Special Education: Interactive Digital Storytelling as a Coaching Approach for Fostering Social Empathy. Procedia Computer Science 67.

DeNatale, Gail Matthews. (2008). Digital Storytelling: Tips and Resources. Boston, MA: Simmons College

Jonassen, H. and Hernandez-Serrano, J. (2002). Case-based reasoning and instructional design using stories to support problem solving. Educational Technology Research and Development, 50 (2), 65-67.

Krashen, Stephen. (2002). Second Language Acquisition and Second Language Learning. California: Pergamon Press Inc.

Mundhe, Ganesh B. (2015). Teaching Receptive and Productive Language Skills The Help of Techniques. Pune Research An International Journal in English, Vol. 1, Issue 2, Sept - Oct.

Papadimitriou, Eleni, et al. (2013). Digital Storytelling in Kindergarten: An Alternative Tool in Children's Way of Expression. Mediterranean Journal of Social Sciences. Vol 4 No 11 October. Doi:10.5901/mjss.2013.v4n11p389

Phillips, Louise. (2016). Role of Storytelling in Early Literacy Development. http://www.australian storytelling.org.au/ Accessed 16 September 2016.

Rahmat, Aceng. (2010). "Implementasi Kurikulum Bahasa Asing di Taman Kanak-Kanak (TK) DKI Jakarta.” Kajian Linguistik dan Sastra. Vol. 22. No. 1, Juni 2010.

Rance-Roney, J. (2008). Digital storytelling for language and culture learning. Essential Teacher, 5(1), 29-31.

Razmi, Mehri, Soheila Pourali, and Sanaz Nozad. (2014). Digital Storytelling in EFL Classroom (Oral Presentation of the Story): A Pathway to Improve Oral Production. Procedia - Social and Behavioral Sciences 98.1541 - 1544.

Robin, Bernard R. (2016). The Power of Digital Storytelling to Support Teaching and Learning Digital Education Review - Number 30, December 2016 - Retrieved from http://greav.ub.edu/der/

Tendero, Antonio. (2006) "Facing versions of the self: The effects of digital storytelling on English education. Contemporary," Contemporary Issues in Technology and Teacher Education, 6 
(2),

Ware, P. D. (2006). From sharing time to show time! Valuing diverse venues for storytelling in technology-rich classrooms. Language Arts, 84 (1), 45-54. 